\title{
Process Management
}

\author{
Kongkiti Phusavat \\ Thailand
}

\section{Introduction}

When dealing with the term process management, people often focus on operational and technical aspects such as production, maintenance, calibration, delivery, and inventory. Nevertheless, the importance on a management process has been recognized more in recent years. For examples, ISO 9001: 2008 specifically focuses on a management process as one of its key requirements. The European Foundation for Quality Management or EFQM Excellent Model explicitly acknowledges the importance of key performance results in the areas of people, customer, and society as well as learning from these results for continuous improvement. The Baldrige Criteria for Performance Excellence Framework highlights the significant contributions from the measurement-analysis-knowledge management component with the results from operational processes and workforce. The Process Classification Framework, proposed by the American Productivity and Quality Center or the APQC, separates process management into two groups; i.e., operating and management/ support categories.

A management process is sometimes referred to as performance management. In general, this term consists of three components. They are performance measurement, analysis, and improvement. A management process has become more important due to the following attributes. In the past, personal experiences may overshadow the importance of performance information when making decisions or taking actions. Given the comprehensive integration of knowledge management in an organization, the use of information for managerial decisions and actions has become more prominent. In addition, performance measurement has gradually evolved from merely generating accountingrelated to more comprehensive information that contains both financial and non-financial information. More managers have become more familiar with the roles of performance measurement. Furthermore, due to the improvement in information and communication technology, databases have become more flexible and robust. Information generated from these databases has become more user-friendly. Finally, the pressure on good governance and accountability has resulted in the increasing use of performance measurementcontinuously generating information based on decisions made and actions taken to improve operational and organizational performance.

To further underline the importance of having an effective management process, other popular models for supplier management such as Capability Maturity Model or CMM have adapted this term extensively. Specifically, the CMM Level 4 indicates all processes have to be quantitatively measured and controlled while its Level 5 highlights the need to use quantitative information to ensure continuous process improvement. It should be noted 
that the CMM has been widely used for the aerospace and defense industries for system and software development and has been part of supplier or contractor risk management.

This chapter is structured and organized as follows. Initially, the focus is on the historical development of a management process as an integral part of process and organizational management. The discussion will later concentrate on introducing tools, techniques, and practices relating a management process, especially for performance measurement. Finally, other standards or frameworks in different industries will be highlighted such as the Control Objectives for Information and related Technology (COBIT) for informationtechnology management will be discussed to help broaden the importance of a management process. Included in this discussion are the trends and the future roles of a management process.

\section{Background}

American Productivity and Quality or APQC earlier developed the Process Classification Framework or the PCF to highlight the importance of process management and continuous performance improvement through benchmarking1. In addition to operations (e.g., production, manufacturing, delivery, new product/ service development, marketing and sale of products/ services, etc.), the term management process has been specifically highlighted. The reason is that, without an effective management process, it is difficult for an organization to drive and fulfill its missions, policies, and objectives (Deming, 1986; Sink \& Tuttle, 1989; and Kursteadt, 1992). A management process indicates a general process in which a manager regardless of his/her level of responsibility within an organization needs to adhere to so that he/she can visualize ongoing problems and forecast future challenges to the workplace. Some of the key activities in the PCF's management process include managing knowledge, improvement, and changes. There are many reasons for its emerging importance. First of all, ISO 9001:2000 drastically changed its structure from the 1987/1994 version with the focus more on an effective management process. The specific requirement dealing directly with this issue was established and was referred to as Measurement, Analysis, and Improvement in its 2000 version. It is important to point out that its most recent version of 2008 maintains this requirement as part of management responsibility 2 .

To highlight the importance of a management process further, several worldwide awards and accepted models have underlined the significance of a management process due its impacts on performance excellence. The Malcolm Baldrige National Quality Award or the MBNQA emphasizes the roles of performance measurement, information analysis, and learning from performance analysis to ensure the ability avoid repeated mistakes and to consistently repeat excellent performance ${ }^{3}$. Its category is specifically named as Measurement, Analysis, and Knowledge Management. The European Foundation for Quality Management Excellent Model or the EFQM focuses on an organization's ability to identify and utilize key performance results on the areas of processes, people, customers,

\footnotetext{
1 See www.apqc.org/pcf (as of 10/18/2009)

2 See www.iso.org/iso/management_standards.htm (as of 10/14/ 2009)

${ }^{3}$ See www.baldrige.nist.gov/ (as of 10/23/2009)
} 
and society in order to ensure constant improvement, learning, and continuous innovation 4 Both the MBNQA and the EFQM commonly stress this role as a means to sustain organizational competitiveness and continuous improvement.

Other accepted models such as the Capability and Maturity Model or CMM explicitly show the need for an organization to quantitatively measure and analyze performance information for sustaining improvement and strengthening its long-term competitiveness 5 . The CMM has been extensively applied for systems and software development and has recently been adapted for contractor risk management-contractor/ supplier audits. According to Blanchard (2008), the CMM was developed by Carnegie Mellon University in 1986. This effort was initiated in response to the request of the U.S. Government to provide a method for assessing the potential risk of its major contractors. The CMM describes an evolutionary improvement path from an ad hoc, immature process to a mature, disciplined process. There are five levels of progressive process maturity - initial, repeatable, defined, managed, and optimizing respectively. The use of quantitative information for monitoring and evaluation represents the managed level or level 4 while the continuous performance improvement reflects the optimizing level or level 5. The lower capability and maturity reflect the inability to achieve and repeat the specific levels of performance required by customers.

The effectiveness of a benchmarking model depends on performance measurement (Sink and Tuttle, 1989; and Dixon et al., 1990). Benchmarking generally involves several key steps such as planning, partner selection, process identification, measuring process performance, information and gap analysis, adaptation of better practices, and process redesign and improvement. APQC has strongly advocated benchmarking as a mechanism for continuous performance improvement in an organization. ${ }^{6}$. Benchmarking helps build knowledge on improvement. Benchmarking represents an effort to become a learning or a knowledgebased organization. It enhances innovation within an organization since the changes in key processes such as new product development, customer complaint handlings, and supplier development are inevitable. In other words, benchmarking can be applied in conjunction with ISO 9001: 2008, the MBNQA, and the EFQM. Even in the public sector, benchmarking has been encouraged. For the U.K., the Public Sector Benchmarking Service, launched in November 2000, aims to promote effective benchmarking and to help share good practices across the public sector 7 . It enables organizations to share knowledge and learn from the best.

Recently, a management process has been the focus of the public sector's reform. An improvement in a management process should positively affect a public agency's operations (Rantanen et al., 2007). Good governance, transparency, accountability highlight the need to have an effective performance measurement which focuses on the outputs and outcomes of an organization in addition to budget disbursement and project/ program management ${ }^{8}$.

\footnotetext{
4 See www.efqm.org (as of 10/25/ 2009)

5 See www.sei.cmu.edu/cmmi/ (as of 10/17/2009)

${ }^{6}$ See www.apqc.org/portal/apqc/site?path=/research/bmm/osbc/index.html

(as of 10/22/2009)

7 See www.archive.cabinetoffice.gov.uk/servicefirst/.../benchmarkingservice.htm (as of 10/25/2009)

8 See www.whitehouse.gov/omb (as of 10/29/2009)
} 
This effectiveness also implies openness and public accessibility into an agency's performance information. Reporting performance results to a general public and representatives in the Parliament and Congress should be mandatory. Key public sector reforms such as Government Performance Results Act of 1993, Government Management Reform Act of 1994, and Program Assessment Rating Tool or PART of 2001 in the U.S. require public agencies to measure, report, and analyze their performance, especially in the areas of impacts, expectations, and fulfillment of citizens' needs ${ }^{9}$.

To specifically ensure that all public agencies are accountable with good governance practices with a great deal of congressional oversights, the Office of Management and Budget of the U.S. government developed a performance measurement- related tool in the early 2000s, known as PART. Information from performance measurement helps complete most of the checklists contained in PART. Moreover, performance measurement also plays a crucial role in implementing value-for-money or performance audits. There are several regions and countries that have performed value-for-money audits such as European Court of Auditors for European countries, Hong Kong, and Singapore. The aim is to ensure the public's confidence and trust in governmental spending. Furthermore, the practices of audits in the public sector have gradually changed from internal (i.e., control, financial and compliance) to performance (sometimes known as value-for-money) audits. For examples, in Finland, Ministry of Finance's Financial Controller advocates the need to demonstrate performance of a public agency in terms of its quality on service delivery, efficiency in cost management, and effectiveness relating to the ability to solve or address citizens' needs ${ }^{10}$. Simply put, the trends in the public sector's reforms and performance audits highlight the importance of a management process within an agency. Eggers (2005) clearly stated that a key success factor for a public agency to become more responsive, accountable, transparent, and efficient depends on its management process as this process drives organizational missions, policies, and objectives.

\section{Management process}

The awareness of a management process' significance in an organization was steadily created by Deming (1986). He unambiguously summarized an entrenched problem that needed to be tackled by American firms into three succinct sentences. "You cannot manage what you cannot measure". This was subsequently followed by "You cannot measure what you cannot define" and "You cannot define what you do not understand." Deming (1986) visualized performance measurement as a key mechanism (decisions should be rational in accordance with information) for a management process. In general, performance measurement plays a critical role in linking an organization with its database and information technology systems. In addition, many firms have used performance measurement as a supporting tool for communicating directions and policies, establishing accountability, monitoring and evaluating activities, establishing goals and benchmarks, and initiating changes to ensure continuous improvement (Hodgetts, 1998). See Figure 1.

${ }_{9}$ See (1) www.whitehouse.gov/omb/mgmt-gpra_gplaw2m,

(2) www. govinfo.library.unt.edu/npr/library/misc/s2170.html, and

(3) www.whitehouse.gov/omb/part (as of 10/26/2009)

10 See www.vm.fi/vm/en/02_ministry/02_organisation_and_functions/12_controller/index.jsp (as of $10 / 31 / 2009$ ) 


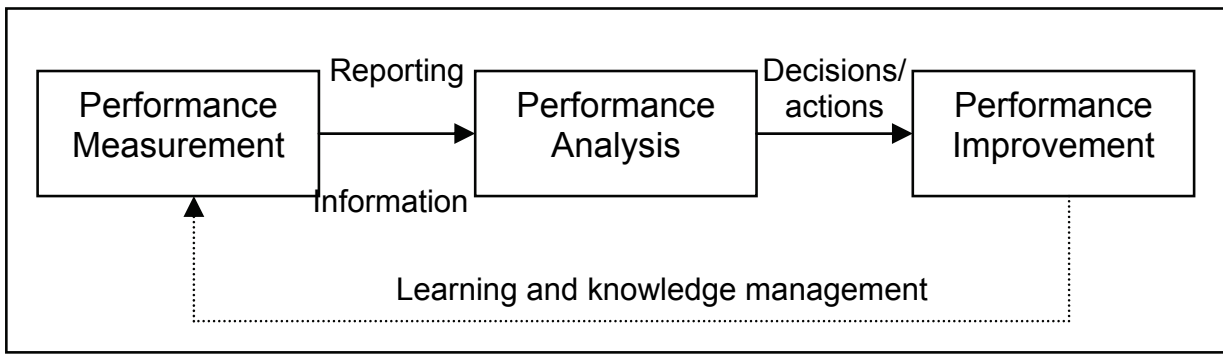

Fig. 1. Management Process Adapted from Deming (1986) and Kursteadt (1992)

Specifically, performance measurement has been increasingly recognized by researchers and practitioners alike over the last two decades (Try \& Radnor, 2007; and Hoque, 2008). Information from performance measurement has evolved from merely accounting-based to more comprehensive financial and non-financial information (Neely, 1998; and Wilson, et al., 2003). Performance measurement addresses the following three issues of concerns (Kurstedt, 1992 and Neely, 1998). How well an organization is performing? Is the organization achieving its objectives? How much has the organization improved from a last period - a trend exists? Simply put, it is critical to become aware of the effectiveness on improvement interventions. Performance measurement represents a system that consists of mechanisms, processes, and criteria or areas of performance (Sink \& Tuttle, 1989; Dixon et al., 1990; Kaplan \& Norton, 1996; and Neely, 2002). Performance measurement needs to be aligned with organizational missions, policies, and objectives (Kaplan \& Norton, 2004). The targets, standards, and benchmarks are typically identified and set through performance measurement (Talluri \& Sarkis, 2002). Information from performance measurement needs to be visible throughout an organization. This helps organizational communication (Vokurka, 2004). See Figure 2 for the roles of and the implications from performance measurement.

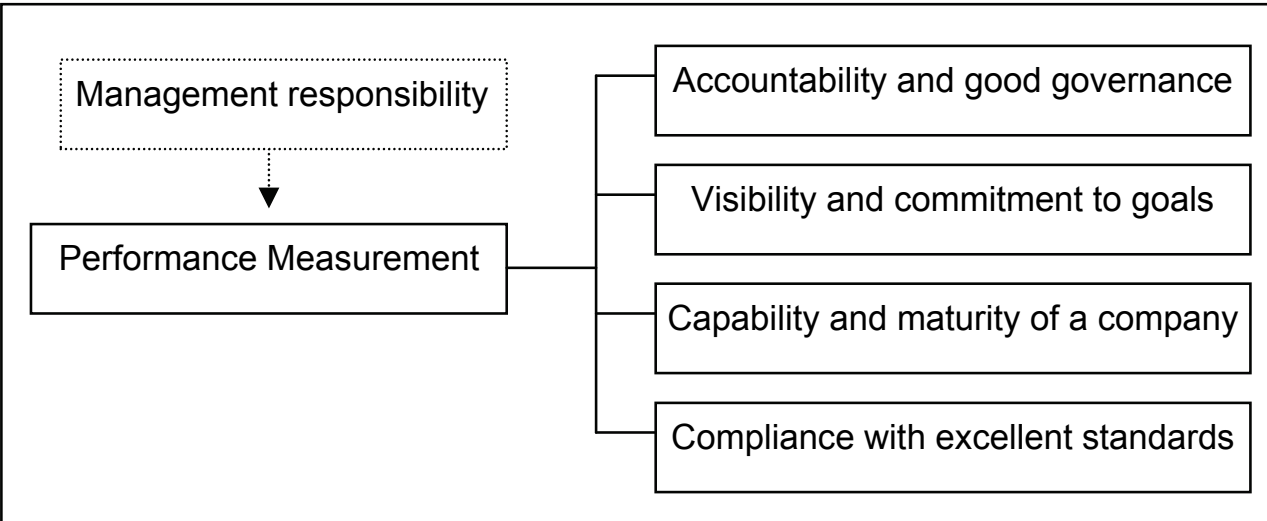

Fig. 2. Roles of Performance Measurement in an Organization

Specifically for measuring at the organizational and functional levels, there are several popular concepts. The Balanced Scorecard concept (Kaplan \& Norton, 2004) has been used to measure organizational performance levels. At the same time, the approach developed by 
Sink (1985), and Sink and Tuttle (1989) has been cited and adapted by several sources in both public and private sectors when measuring their functional and organizational performance. According to Sink and Tuttle (1989), the term performance is a function of profitability, productivity, quality, quality of work life (QWL), innovation, effectiveness, and efficiency. On the other hand, Harper (1984), suggested that there were seven areas when measuring performance. Included are, for examples, productivity, unit cost, price, and so on. There are also other concepts that are more practical and business oriented such as the Balanced Scorecard where performance needs to have information from the four viewpoints; i.e., financial, customer, internal business processes, and innovation and learning areas (Kaplan \& Norton, 1996). Neely (2002) also suggested that the concept of performance prism with different facets for required information. See Table 1 for the summary of performance measurement.

\begin{tabular}{|l|l|l|}
\hline \multicolumn{1}{|c|}{ Concepts } & \multicolumn{1}{|c|}{ Measurement Areas } & \multicolumn{1}{c|}{ Application } \\
\hline Harper (1984) & $\begin{array}{l}\text { Productivity, unit cost, price, } \\
\text { factor proportion, cost } \\
\text { proportion, product mix, and } \\
\text { input allocation }\end{array}$ & $\begin{array}{l}\text { Functional and operational } \\
\text { levels }\end{array}$ \\
\hline $\begin{array}{l}\text { Sink (1985) and Sink and } \\
\text { Tuttle (1989) }\end{array}$ & $\begin{array}{l}\text { Profitability, productivity, } \\
\text { quality, effectiveness, } \\
\text { efficiency, quality of work } \\
\text { life, and innovation }\end{array}$ & $\begin{array}{l}\text { Organizational, functional, } \\
\text { and operational levels }\end{array}$ \\
\hline Neely (2002) & $\begin{array}{l}\text { Stakeholders (i.e., customer } \\
\text { and intermediaries, } \\
\text { employees, suppliers, } \\
\text { regulators and communities, } \\
\text { and investors), strategies, } \\
\text { capabilities, processes }\end{array}$ & $\begin{array}{l}\text { Organizational, functional, } \\
\text { and operational levels }\end{array}$ \\
\hline Kaplan and Norton (2004) & $\begin{array}{l}\text { Shareholders, finance, } \\
\text { internal business, and } \\
\text { innovation and learning }\end{array}$ & Organizational level \\
\hline
\end{tabular}

Table 1. Summary of Performance Measurement Concepts

To bring to light the comprehensiveness of performance measurement, the productivity perspective is used for this revelation. Specifically, when focusing on the industrial, national, and international levels, many approaches have been designed by economists such as the Total Factor Productivity (TFP), or Bureau of Labor Statistics (BLS) multifactor productivity techniques (Duke \& Torres, 2005; Meyer \& Harper, 2005). At the organizational, functional, program, and project levels, there have been several concepts and ideas involving in the measurement/ assessment work. Harper (1984) also developed a performance measurement framework at the organizational/ functional levels. Other frameworks and methods at the organizational/ functional level include Multi-factor Productivity Measurement Model and value-added productivity (Sink, 1985). Sumanth (1998) also advocated the importance of total productivity measurement. At the group and individual levels, there were many concepts such as motivational methods based on industrial psychologists and performance appraisals for salary structure/ workload analysis extended by human resource specialists, and piece-rate/ standard times determined by 
industrial engineers (Barnes, 1980). Recent developments for productivity measurement for white-collar workforce have included the integration of immediate customers and key stakeholders into this effort. See Table 2.

\begin{tabular}{|l|l|l|}
\hline \multicolumn{1}{|c|}{ Applications } & \multicolumn{1}{|c|}{ Productivity Measurement } & \multicolumn{1}{c|}{ Sources } \\
\hline $\begin{array}{l}\text { Industrial and } \\
\text { national levels }\end{array}$ & $\begin{array}{l}\text { (1) Total Factor Productivity } \\
\text { (2) Bureau of Labor Statistics' } \\
\text { Multifactor Productivity }\end{array}$ & $\begin{array}{l}\text { Duke and Torres (2005) } \\
\text { Meyer and Harper (2005) }\end{array}$ \\
\hline Organizational level & $\begin{array}{l}\text { (1) Multi-factor Productivity } \\
\text { Measurement Model by APQC } \\
\text { (2) Use of surrogate (e.g., } \\
\text { profitability, etc.) }\end{array}$ & Sink and Tuttle (1989) \\
\hline $\begin{array}{l}\text { Functional and } \\
\text { operational levels } \\
\text { (for projects and } \\
\text { processes) }\end{array}$ & $\begin{array}{l}\text { (1) Productivity network } \\
\text { (2) Multi-criteria Productivity } \\
\text { Measurement Technique (including } \\
\text { an integration of metrics or ratios) } \\
\text { (3) Use of surrogate (e.g., quality of } \\
\text { work life, profitability, quality, } \\
\text { efficiency, etc.) }\end{array}$ & $\begin{array}{l}\text { Harper (1984) } \\
\text { Sink and Tuttle (1989) } \\
\text { (4) Total productivity management }(1990) \\
\text { Sumanth (1998) } \\
\text { Hoehn (2003) }\end{array}$ \\
\hline $\begin{array}{l}\text { (5) Value-added Productivity } \\
\text { Groups or teams }\end{array}$ & $\begin{array}{l}\text { (1) Use of surrogate (e.g., } \\
\text { stakeholder satisfaction - high } \\
\text { satisfaction of stakeholders } \\
\text { reflecting productiveness of staffs) } \\
\text { (2) Zigon's approach }\end{array}$ & $\begin{array}{l}\text { Hodgetts (1998) } \\
\text { Zigon (1998) }\end{array}$ \\
\hline $\begin{array}{l}\text { Individual (e.g., } \\
\text { white-collar or } \\
\text { knowledge work, } \\
\text { and blue-collar } \\
\text { workforces) }\end{array}$ & $\begin{array}{l}\text { (2) Use of surrogate (e.g., } \\
\text { stakeholder satisfaction- high } \\
\text { satisfaction of stakeholders } \\
\text { reflecting productiveness of staffs) } \\
\text { (3) Zigon's approach }\end{array}$ & $\begin{array}{l}\text { Bodgetts (1998) } \\
\text { Zigon (1998) }\end{array}$ \\
\hline
\end{tabular}

Table 2. Summary of Productivity Measurement (Source: Phusavat et al., 2009)

Information analysis is critical for continuous performance improvement. It generally involves the use of statistical techniques as well as other quality-related tools such as the Fishbone and Pareto Diagrams ${ }^{11}$. When applying statistics for performance analysis, the underlying question is whether a trend exists that merits the attention from management. In addition, basic quality control tools should be adapted to help strengthen statistical analysis. They are altogether 14 tools for quality and performance analysis (in accordance to Institute for Small and Medium Enterprise Development at www.ismed.or.th/SME/ src/bin/controller). The trend analysis is important due to the need to further understand whether a trend can be attributed to special or common causes. Common causes require strong attention and circumstance awareness from management. On the other hand,

11 See www. en.wikipedia.org/wiki/Seven_Tools_of_Quality (as of 10/24/2009) 
benchmarking can help performance analysis as it is important for an organization realizes whether its performance exceeds benchmarking partners. If not, adapting better practices from benchmarking partners for process improvement is necessary. Analyzing performance results with a set of targets is also common. It is important to note that Deming (1986) warned against using the targets that were not reasonably developed. This could lead to the decisions from performance analysis to be irrational and might cause the conflicts between management and organizational workforce. If this problem can be overcome, the quality of performance analysis can be greatly enhanced. Kaplan and Norton (2004) provided a strategy map that could be adapted for performance analysis and evaluation. Performance information when comparing with a strategy map indicates whether actual results meet with the expectation or anticipation earlier designed (in this map).

Performance improvement deals with decisions and actions when tackling current problems or preventing potentially undesirable circumstances for an organization or a function. Recent improvement interventions in both private and public sectors have involved human capital development, knowledge management, outsourcing and supply-chain management, customer relation management, investment in information and communication technology, machinery investment, quality management, production and resource planning, layout improvement, public-private partnership, contestability, and so on (Neely, 2002; and Nisar, 2007). These interventions can focus on the inputs (e.g., labor, capital, machines/ equipment, materials, facility and layout, etc.), organizational and functional operations (e.g., work simplification, elimination of unnecessary tasks, and process combination and reengineering), and outputs (e.g., products and services). Planning for a possible change has to be carefully made as it deals with people and their feeling (Neely, 1998). Managing expectation on the impacts of improvement is also important during this stage in a management process. Despite the various ways to improve the performance levels, repeatedly measuring their impacts on key areas (mentioned earlier in Table 1) is necessary in order to reflect how effective and how well an improvement intervention is carried out.

\section{How to measure performance}

Sink and Tuttle (1989) clearly outlined, described, and demonstrated how to measure performance. Measuring performance requires the following tasks. The first task is the use of Input and Output (I/O) Analysis to ensure that a total or a system viewpoint is integrated. The I/O Analysis is used to understand an organization's upstream- inputsprocesses- outputs- downstream chain. Without this analysis, an effort to identify key performance indicators might not succeed. See Figure 3. The second task deals with identifying key performance indicators in a ratio format. The reason for this format is due to the need to normalize information for performance analysis. The third task is the unambiguous definition of key performance criteria. Finally, the fourth task deals with the activities relating to the management of an organization's database, including data collection, storage, and information report.

According to Sink and Tuttle (1989), with an organizational analysis from the system's viewpoint, it is possible to have several ratio-format key performance indicators. On the other hand, clear definitions are needed. From Phusavat (2007), based on Sink (1985) and Sink and Tuttle (1989), for a case company, profitability examines the interrelationships between revenues and total costs, and the company's profit margin. Quality focuses on assuring compliance of inputs and outputs as specified by an organization and its clients. 


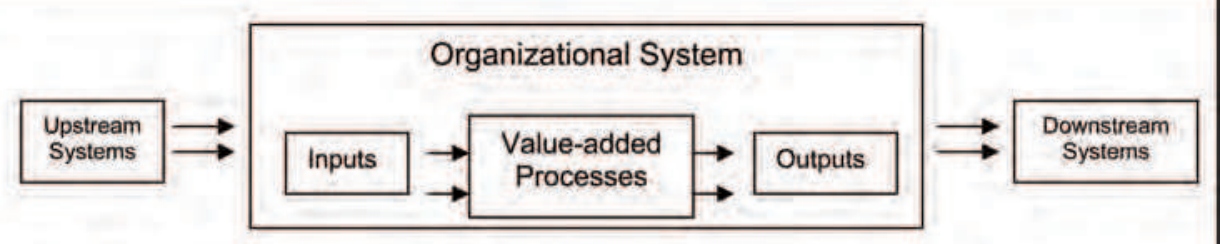

Downstream: customers, requirements from customers, revenue, and so on.

Outputs: products and services such as delivery

Value-added processes: production, inspection, purchasing, delivery, sales, and so on

Inputs: labor, materials, utilities, facility, machines, tools, and so on

Upstream: suppliers and needs from suppliers

Fig. 3. I/O Analysis (Source: Phusavat, 2007)

Quality of Work Life scrutinizes how people feel about such things as their job, and working conditions. In this case company, absenteeism and work stoppages (likely due to injuries and safety problems) reflect the main concern from top management. Finally, for innovation, it concentrates on an organization's ability to respond to changes in customer preferences such as identifying and obtaining contracts from new customers or from new tools (representing new products for either new or existing customers). Some of the ratioformat key performance indicators can be demonstrated as follows.

1. Profitability Criterion

(1.1) Revenue $\div$ Total cost

(1.2) Rate of change in revenue $\div$ Rate of change in cost

(1.3) Profit $\div$ Revenue

(1.4) \% of sale revenue from rework

2. Quality Criterion:

(2.1) \% Delay in delivery

(2.2) \% Delivery error

(2.3) \% Rework (relatively to output value)

(2.4) \% Return (relative to output value)

(2.5) \% of rejects on incoming materials

3. QWL Criterion

(3.1) \% Injury cost at the workplace (relative to operating cost)

(3.2) Unplanned absent period $\div$ Working period

(3.3) Work stoppage period $\div$ Working period

4. Innovation Criterion:

(4.1) \% Revenue from new design

(4.2) \% Revenue from new customers

(4.3) Cycle time for new work-design completion (after receiving a drawing order from a customer)

The next step in measuring performance involves data collection and generates information or performance reports for management reviews. It is important to note that clear definition of performance criteria and understandable definitions of terms for each key performance indicators, including unit dimension (e.g., \$, hours, pieces, $\mathrm{m}^{2}$, and $\mathrm{m}^{3}$ ) and frequency (e.g., 
hourly, daily, weekly, monthly, and quarterly), are important. Furthermore, the preference on either a graphical or a tabular format should be stated. See both Table 3 and Figure 4.

\begin{tabular}{|c|c|c|}
\hline Period & $\begin{array}{c}\text { Unplanned absent period } \div \\
\text { Working period in \% (from hours } \\
\text { to hours) }\end{array}$ & $\begin{array}{c}\text { Work stoppage period } \div \\
\text { Working period in \% (from } \\
\text { hours to hours) }\end{array}$ \\
\hline July 02 & 1.96 & 0.75 \\
\hline August 02 & 2.55 & 0.96 \\
\hline September 02 & 1.02 & 0.60 \\
\hline October 02 & 2.04 & 0.63 \\
\hline November 02 & 1.59 & 1.61 \\
\hline December 02 & 0.70 & 0.86 \\
\hline January 03 & 1.01 & 0.78 \\
\hline February 03 & 1.79 & 0.98 \\
\hline March 03 & 1.22 & 1.31 \\
\hline April 03 & 0.92 & 0.82 \\
\hline May 03 & 0.90 & 1.90 \\
\hline June 03 & 1.18 & 2.18 \\
\hline
\end{tabular}

Table 3. Tabular Format for Quality of Work Life Performance Results (Source: Phusavat, 2007)

Note:

- Unplanned absent period: number of hours that workers are absent without prior notice.

- Work stoppage period: number of hours that production line stops due to safety and health of workers

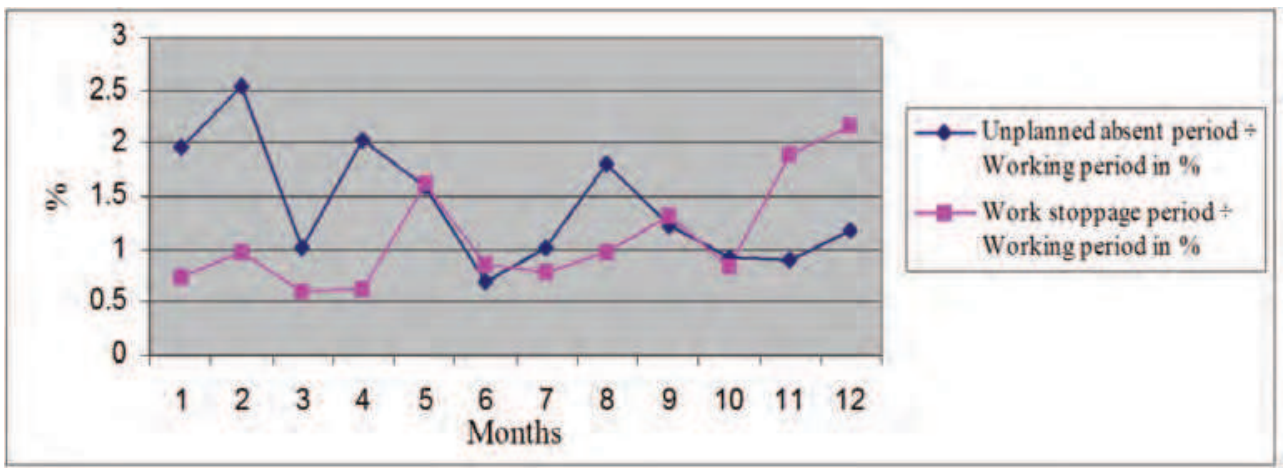

Fig. 4. Graphical Format of Quality of Work Life Performance Results (Source: Phusavat, 2007) 


\section{Viewpoints on performance measurement and analysis}

The interviews with six organizations aim to help learn more about their current practices on a management process, especially in the areas of performance measurement and analysis. All six firms have completed the applications of the Thailand Quality Award (TQA). The TQA represents one of the most recognized awards for all industries in Thailand ${ }^{12}$. It is part of the overall joint efforts by the public and private sectors to promote the long-term competitiveness and continuous performance improvement. The TQA is essentially identical to the MBNQA. It is important at this point to recognize that the MBNQA has been adapted by many countries such as India (Rajive Gandhi National Quality Award), Malaysia (Prime Minister Quality Award), Singapore (i.e., Singapore Quality Award), Taiwan (Taiwan National Quality Award), United Arab Emirates (Dubai International Award for Best Practices), and Vietnam (Vietnam Quality Award).

Two of the six organizations received the TQA while the remaining four firms were recognized for their Thailand Quality Class (i.e., the first step towards the TQA). The Thailand Quality Class was created for an organization that its score, after two rounds of an independent review, is given between 350 to 550 points $^{13}$. Only an organization that receives a score more than 550 points is nominated for the TQA. The interviews take place with both Chief Executive Officers (CEOs) and Chief Quality Officers (CQOs). Four firms are classified as a manufacturer while two companies were considered as a service provider. For manufacturing firms, they operate in the food, petro-chemical, and textile businesses. For service providers, both organizations are in the healthcare businesses.

CEOs and CQOs have indicated that performance measurement is a necessary tool for successful management. It has improved the quality of information analysis and decisionmaking processes. Since all six companies are ISO 9001 certified, they view Requirement 8 to be directly under their responsibilities. From their perspective, performance measurement underlines the change towards management by objectives, information, and knowledge. It has resulted in less reliance on experiences and judgment which could lead to wrong problem solutions and the opposition or resistance by staffs. Recent investment in their respective organizations on information and communication technology has been worthwhile as more timely and accurate information become available to management, staffs, suppliers, and even customers. As indicated in the TQA, if performance measurement properly used, it can tremendously help knowledge management as organizational-related information should constantly be shared and communicated. Learning from past mistakes such as errors and customer complaints is necessary for long-term competitiveness. See Table 3 for more details of their feedback.

Given the opinions expressed by both CEOs and CQOs, it is interesting to note that a relatively consistent perspective has emerged on performance measurement. They have indicated that performance has gradually moved from merely an afterthought management tool to become an integral part of a quality management system. More vigorous use of performance measurement highlights the change in management styles within an organization. Performance measurement-related tasks such as identifying an appropriate set

\footnotetext{
12 www.tqa.or.th/th/tqa-history (as of 8/15/2009)

${ }^{13}$ www.tqa.or.th/th/node/690 (as of 8/30/2009)
} 
of key performance indicators and communicating the target levels to staffs within an organization essentially represents fundamental responsibilities of top management. Performance measurement also is regarded as an important management tool to help direct an organization and/or an operation. Performance measurement is viewed as a prerequisite for attaining a learning behavior (Putu et al., 2007). This behavior is nowadays critical in the era of globalization in which a company has to operate with the limited resources but face competitors around the globe (Sheng \& Trimi, 2008).

\begin{tabular}{|c|c|}
\hline Comments on Performance Measurement & General Viewpoints \\
\hline $\begin{array}{l}\text { It highlights the requirements and responsibility of } \\
\text { management. }\end{array}$ & \multirow[t]{3}{*}{$\begin{array}{l}\text { Reflecting management } \\
\text { responsibility }\end{array}$} \\
\hline $\begin{array}{l}\text { Management without performance information is } \\
\text { risky and irresponsible. }\end{array}$ & \\
\hline $\begin{array}{l}\text { It represents a milestone of effective management- } \\
\text { when there is no performance measurement, it } \\
\text { implies a serious failure on management. }\end{array}$ & \\
\hline It can be considered as an information provider. & \multirow{7}{*}{$\begin{array}{l}\text { Representing a management tool } \\
\text { (e.g., a decision-making process } \\
\text { that is based on performance } \\
\text { information) }\end{array}$} \\
\hline $\begin{array}{l}\text { It represents a more systematic mechanism for } \\
\text { feedback and information. }\end{array}$ & \\
\hline It reflects a more systematic decision-making process. & \\
\hline $\begin{array}{l}\text { It can be utilized with accounting information for } \\
\text { better insights into a company's operations. }\end{array}$ & \\
\hline $\begin{array}{l}\text { It provides feedback for planning and strategic } \\
\text { decisions. }\end{array}$ & \\
\hline It helps link database with managerial decisions. & \\
\hline $\begin{array}{l}\text { It helps realize benchmarking efforts in an } \\
\text { organization. }\end{array}$ & \\
\hline $\begin{array}{l}\text { It increases more acceptances from staffs when } \\
\text { making policy initiatives and decisions. }\end{array}$ & \multirow[t]{3}{*}{$\begin{array}{l}\text { Indicating a strength of a quality } \\
\text { management system }\end{array}$} \\
\hline $\begin{array}{l}\text { It improves communications between management } \\
\text { and workforce with greater visibility. }\end{array}$ & \\
\hline $\begin{array}{l}\text { It provides visibility to all staffs so that possible } \\
\text { changes in operations and processes can take place } \\
\text { quite easily. }\end{array}$ & \\
\hline $\begin{array}{l}\text { It represents groundwork for making operations in } \\
\text { an organization more repeatable and predictable (as } \\
\text { the focus is on variations - root causes of a problem } \\
\text { instead of random attributes). }\end{array}$ & $\begin{array}{l}\text { Attaining desirable } \\
\text { characteristics from external } \\
\text { parties - competency and } \\
\text { capability }\end{array}$ \\
\hline
\end{tabular}




\begin{tabular}{|l|l|}
\hline \multicolumn{1}{|c|}{ Comments on Performance Measurement } & \multirow{2}{*}{ General Viewpoints } \\
\hline $\begin{array}{l}\text { It strengthens working environment that focuses } \\
\text { improvement such as a use of benchmarking } \\
\text { practices. }\end{array}$ & \\
\cline { 1 - 2 } $\begin{array}{l}\text { It symbolizes competency of top management and } \\
\text { capability of an organization due to the commitment } \\
\text { towards accountability. }\end{array}$ & \\
\cline { 1 - 2 } $\begin{array}{l}\text { It represents a foundation of knowledge management } \\
\text { as required by the TQA. }\end{array}$ & $\begin{array}{l}\text { Supporting an effort on } \\
\text { becoming a Learning or } \\
\text { knowledge-based organization }\end{array}$ \\
\cline { 1 - 1 } $\begin{array}{l}\text { It provides positive atmosphere for all staffs where } \\
\text { performance information is visible as it indicates } \\
\text { transparent and good corporate governance. }\end{array}$ & \\
\cline { 1 - 2 } $\begin{array}{l}\text { It can enhance a learning capability of an } \\
\text { organization as there is more visibility for everyone. }\end{array}$ & \\
\cline { 1 - 2 } $\begin{array}{l}\text { Information should be made available and accessible } \\
\text { to staffs in regard to organizational and functional } \\
\text { performance, and possible improvement } \\
\text { interventions. }\end{array}$ & \\
\hline
\end{tabular}

Table 3. Perspectives on Performance Measurement (Adapted from Phusavat et al., 2009)

\section{Management process in the future}

For private firms, the continued acceptance and applications of ISO 9001: 2008, the CMM, the MBNQA, the EFQM, and benchmarking highlight a need to strengthen a management process. Recent studies have advocated a better linkage between a management process, and information and communication technology design, especially in the areas of database robustness, cognitive styles of managers, quality of a management report, etc (Eggers, 2005; and Sheng \& Trimi, 2008). For examples, the Control Objectives for Information and related Technology (COBIT) is a set of best practices (framework) for IT management ${ }^{14}$. COBIT was earlier developed by the Information Systems Audit and Control Association and the IT Governance Institute in 1996. COBIT helps address several critical issues relating to a management process, including the accuracy of data on the performance levels and the integration of performance information and reports into decision-making processes at all levels within an organization.

The Information Technology Infrastructure Library (ITIL) is a set of recommended practices for managing the Information and communication technology services during design, planning, deployment, operations, and upkeep. ITIL is a registered trademark of the United Kingdom's Office of Government Commerce. ITIL can benefit a management process in several ways. First of all, ITIL addresses the risk involving data security and verification on

\footnotetext{
14 See www.isaca.org/cobit (as of 10/17/ 2009)
} 
authentic accessibility ${ }^{15}$. Business disaster recovery plan represents key ITIL consideration as an organization needs to maintain its capability to recover important data and information when needed. This is critical for timely responses and crisis or emergency management. Secondly, ITIL focuses on how a database is managed, ranging from data collection, data storage, data release and retrieval, and information report. As indicated earlier, quality of information (e.g., accuracy, reliability, timeliness) influences the quality of decisions and actions by top management.

Finally, a management process at the present time symbolizes and reflects the transparency in an organization. From the wisdom of Deming (1986) to ISO 9001: 2008, the MBNQA, and the EFQM; the roles and importance of a management process has been increasingly recognized. In fact, it is singled out by the APQC's PCF. It is even nowadays embedded in popular frameworks such as the CMM and is an integral part of ongoing public sector reforms around the world. A management process helps describe foremost responsibility for all managers. It illustrates that a manager should be accountable for his/her decisions and actions as their impacts are continuously measured. More importantly, a management process helps drive organizational missions, policies, and objectives. In addition, a management process strengthens organizational capability to overcome current competition and to better prepare for future endeavors in the globalization era. Therefore, an effective management process should benefit any organization operating under financial limitations, demographic changes, changing expectations of customers and/or citizens.

\section{References}

Barnes, R. (1980) Motion and time study: design and measurement of work, John Wiley \& Sons: New York.

Blanchard, B., (2008), System Engineering and Management, John Wiley, Singapore

Deming, W. (1986), Out of Crisis, MIT Center for Advanced Engineering Study: MA

Dixon, J., Nanni, A., and Vollman, T. (1990) The New Performance Challenge: Measuring Operations for World Class Competition, Business One Irwin, Homewood, IL

Duke, J. and Torres V. (2005) "Multifactor productivity change in the air transportation industry", Monthly Labor Review (sponsored by Bureau of Labor Statistics, Department of Labor, USA), March

Eggers, W. (2005) Government 2.0: using technology to improve education, cut red tape, reduce gridlock, and enhance democracy, Rowman \& Littlefield Publishers, NY

Harper, J. (1984) Measuring Business Performance, Institute of Manpower Studies, Gower Publishing, the U.K

Hodgetts, R., (1998), Measures of Quality and High Performance, AMACOM: New York

Hoque, Z. (2008) "Measuring and reporting public sector outputs/outcomes: exploratory evidence from Australia", International Journal of Public Sector Management, Vol. 21, No. 5, pp. 468- 493

15 See www.itil-officialsite.com/home/home.asp (as of 10/19/2009) 
Kaplan, R. and Norton, D. (1996) The Balanced Scorecard: Translating Strategy into Action, Harvard Business School Press

Kaplan, R. and Norton, D. (2004) The Strategy Maps, Harvard Business School Press

Kurstedt, H., (1992), Management System Theory and Practices, Course Lectures for ISE 4015, 4016, and 5004, Department of Industrial and Systems Engineering at Virginia Tech

Meyer, P. and Harper M. (2005) "Preliminary estimates of multifactor productivity growth", Monthly Labor Review (sponsored by Bureau of Labor Statistics, Department of Labor, USA), June

Neely, A. (1998), Measuring Business Performance, Economist Books, London

Neely, A. (2002) Business Performance Management Theory and Practice, Cambridge University Press

Nisar, T. (2007) "Value for money drivers in public-private partnership schemes", International Journal of Public Sector Management, Vol. 20, No. 2, pp. 147- 156

Phusavat, K. (2007) "Roles of performance measurement in SMEs' management processes," International Journal of Management and Enterprise Development, Vol. 4, No.4, pp. 441 458

Phusavat, K., Anussornnitisarn, P., Helo, P., and Dwight, R. (2009) "Performance measurement: roles and challenges," Industrial Management $\mathcal{E}$ Data Systems, Vol. 109, No. 5, pp. 646-664

Putu, N., Mimba, S., van Helden, G., and Tillema, S. (2007) "Public sector performance measurement in developing countries: a literature review and research agenda", Journal of Accounting \& Organizational Change, Vol. 3, No. 3, pp. 192- 208

Rantanen, H., Kulmala, H., Lonnnqvist, A., and Kujansivu, P. (2007) "Performance measurement systems in the Finnish public sector", International Journal of Public Sector Management, Vol. 20, No. 5, pp. 415- 433

Sheng, H. and Trimi, S. (2008) "M-government: technologies, applications, and challenges", Electronic Government, An International Journal, Vol. 5, No. 1, pp. 1- 18

Sink, D. (1985) Productivity Management Planning Measurement and Evaluation Control and Improvement, John Wiley \& Sons, NY

Sink, D. and Tuttle, T. (1989) Planning and Measurement in Your Organization of the Future, IE Press, GA

Sumanth, D. (1998) Total productivity management, St. Lucie Press, FL

Talluri, S. and Sarkis, J. (2002) "A model for performance monitoring suppliers", International Journal of Production Research, Vol. 40, No. 16, pp. $4257-4269$

Try, D. and Radnor, Z. (2007) "Developing an understanding of result-based management through public value theory", International Journal of Public Sector Management, Vol. 20, No. 7, pp. 655- 673

Wilson, C., Hagarty, D., and Gauthier, J. (2003) "Results using the balanced scorecard in the public sector", Journal of Corporate Real Estate, Vol. 6, No. 1, pp. 53- 64

Vokurka, R. (2004) "Operationalising the balanced scorecard using the Malcolm Baldrige Criteria for Performance Excellence (MBCPE)", International Journal of Management and Enterprise Development, Vol. 1 No. 3, pp. 208- 217 
Zigon, J. (1998) "Measuring the hard stuff: teams and other hard-to-measure work", from the Zigon Performance Group Web Site (available at: www.zigonperf.com as of October $15^{\text {th }} 2005$ ) 


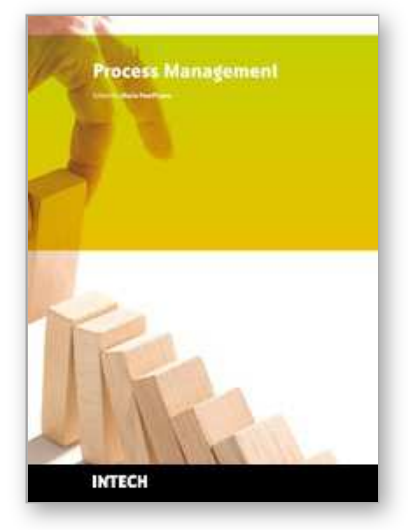

\author{
Process Management \\ Edited by Maria Pomffyova
}

ISBN 978-953-307-085-8

Hard cover, 338 pages

Publisher InTech

Published online 01, April, 2010

Published in print edition April, 2010

The content of the book has been structured into four technical research sections with total of 18 chapters written by well recognized researchers worldwide. These sections are: 1. process and performance management and their measurement methods, 2. management of manufacturing processes with the aim to be quickly adaptable after real situation demands and their control, 3. quality management information and communication systems, their integration and risk management, 4. management processes of healthcare and water, construction and demolition waste problems and integration of environmental processes into management decisions.

\title{
How to reference
}

In order to correctly reference this scholarly work, feel free to copy and paste the following:

Kongkiti Phusavat (2010). Process Management, Process Management, Maria Pomffyova (Ed.), ISBN: 978953-307-085-8, InTech, Available from: http://www.intechopen.com/books/process-management/processmanagement

\section{INTECH}

open science | open minds

\section{InTech Europe}

University Campus STeP Ri

Slavka Krautzeka 83/A

51000 Rijeka, Croatia

Phone: +385 (51) 770447

Fax: +385 (51) 686166

www.intechopen.com

\section{InTech China}

Unit 405, Office Block, Hotel Equatorial Shanghai

No.65, Yan An Road (West), Shanghai, 200040, China

中国上海市延安西路65号上海国际贵都大饭店办公楼405单元

Phone: $+86-21-62489820$

Fax: +86-21-62489821 
(C) 2010 The Author(s). Licensee IntechOpen. This chapter is distributed under the terms of the Creative Commons Attribution-NonCommercialShareAlike-3.0 License, which permits use, distribution and reproduction for non-commercial purposes, provided the original is properly cited and derivative works building on this content are distributed under the same license. 